\title{
Developing Sub-Bituminous Coal Sintering Ratio for Predicting Coal Ash Slagging Factors
}

\author{
Salmi Samsudin ${ }^{1,2^{*}}$, Nuraini Abdul Aziz ${ }^{1}$, Abdul Aziz Hairuddin ${ }^{1}$, Siti Ujila Masuri ${ }^{1}$ \\ ${ }^{1}$ Department of Mechanical \& Manufacturing, Faculty of Engineering, University Putra Malaysia, 43400 \\ Serdang, Selangor, Malaysia \\ ${ }^{2}$ TNB Janamanjung Sdn Bhd, Stesen Janakuasa Sultan Azlan Shah, 32400 Manjung, Perak, Malaysia
}

\begin{abstract}
Fossil fuels such as coal, gas, and distillate are the core fuels for thermal plants. The thermal coal-fired power plant accounts for $40 \%$ of global electricity generation. The thermal coal plant is expected to continue generating electricity until 2040 , covering roughly $60-75 \%$ of the energy demand. Coal is largely used as fuel in thermal power plants in generating electricity. Coal ash causes slagging and fouling at the boiler in the furnace, superheater tube, and pendant tube. Thus, the prediction of coal slagging and fouling is imperative for forecasting boiler repair work and outage. Therefore, this study was conducted in a thermal coal-fired power plant generating 700 megawatts. X-ray diffraction analysis (XRD) was applied to analyze the ash composition. A coal sintering method was developed as an indicator to predict ash slagging. Several coals with different characteristics were selected to conduct the coal ash analysis. Furthermore, sub-bituminous coal sintering indexes for predicting coal ash slagging factors were also developed. From this study, there are minimal ash deposition tendencies for sub-bituminous coal ash with a low sinter ratio of 0.2 , whereas the ash deposition tendencies are high for high sinter ratios of 0.8 and above.
\end{abstract}

Keywords: Coal ash slagging; Sintering ratio; Slagging factors; Sub-bituminous coal

\section{Introduction}

The global demand of electricity increases by about $1.1 \%$ in 2018 , after declining for the last three years from 2017. Coal as the main fuel is leading by about $2 \%$ from the thermal plant in generating electricity (Samsudin and Abd Aziz, 2020). Over the next five years, global coal demand is forecasted to remain stable, supported by the resilient Chinese market, which accounts for half of global consumption. In fact, thermal coal plants cover about $38 \%$ of the power market share as the largest sources. The largest share comes from Asian countries, China, and India, while Europe and North America keep on reducing the consumption of coal thermal generation. In the non-power sectors, despite much coal-togas switching in China, the demand remained stable (Tiwary, 2001). The international coal trade grew by $4 \%$ in 2018, surpassing 1.4 billion tonnes. In 2019, coal was the major fuel in generating power at a fired power plant for the Asian country. In fact, $75 \%$ of power generation in China and Indonesia is generated by coal-fired power plants. Coal resources from nature are categorized as non-renewable resources.

Coal can be classified into bituminous, sub-bituminous, and lignite (brown) by

${ }^{*}$ Corresponding author's email: nasmiesan@gmail.com, Tel.: +06-019-2932042

doi: 10.14716/ijtech.v12i4.4892 
referring to its calorific value. Besides, coal content includes hydrogen, sulfur, nitrogen, and carbon (Samsudin et al., 2020a). The coal content highly contributes the combustion efficiency and an indicator for formation of slagging and fouling deposition. Coal is heated in the boiler throughout the pulverizer.

Ash slagging is formed on the radiant heat transfer section in the furnace area. (Pozzoli et al., 2015; Abd Aziz et al., 2018). Ash fouling is deposited at the superheated (SH) and reheated $(\mathrm{RH})$ regions from the result of convection. Meanwhile, low-temperature fouling is formed at the economizer region. Consequently, the formation of coal ash slagging decreases plant efficiency and availability (Ahmad et al., 2015). In addition, the accumulation of ash in the boiler tube reduces heat transfer, decreases efficiency, and impacts the reliability of the boiler. Thus, predicting ash formation in the boiler furnace provides an advantage in managing the coal and operation of the boiler (Sushil and Batra, 2006; Abd Aziz et al., 2019). Figure 1 shows the ash deposition area, ash slagging, and ash fouling in the boiler furnace.

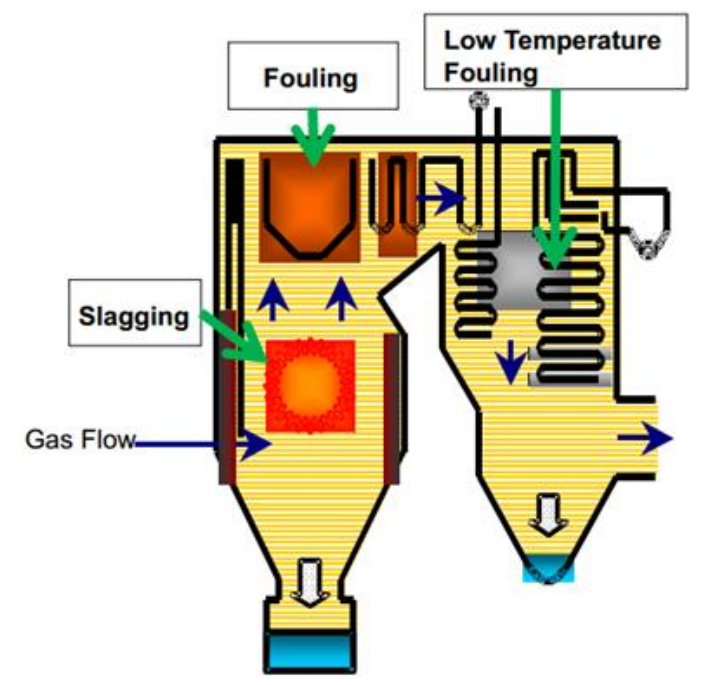

Figure 1 Coal ash deposition area in boiler furnace

Prediction of coal ash formation helps maintain a sustainable boiler operation. Coal bituminous slagging indices have been introduced, which are now widely used for predicting slagging in boiler furnaces (Samsudin and Abd Aziz, 2020). However, these indices are only applicable for bituminous coal and cannot be used for coal with lower ranks, such as lignite and sub-bituminous coal (Krevelen, 1993; Speight, 2015). Therefore, a new slagging index is required for low-rank coal. The sintering test is used to determine the resistance of sintering coal ash. Consequently, through the sintered test, the coal slagging indices for sub-bituminous coal can be developed (Speight, 2015).

\section{Literature Review}

Coal is a solid fuel that contains carbon, hydrogen, sulfur, oxygen, and nitrogen. Coal is known as combustible fossil fuel and is used largely in other industries activities. Coal with different coal specifications results in different behaviors and characteristics (Sushil and Batra, 2006). Coal analysis techniques are specific analytical methods designed to measure the particular physical and chemical properties of coals (Krevelen, 1993). Furthermore, coal was mostly used in thermal coal plants as the main fuel, with the firing process taking place in a large utility boiler. Coal remains a choice as the main fuel in the electricity industry due to the competitive price of the fuel with minimum cost in generating power. Firing coal can 
cause several issues, such as air pollution to the environment, emissions, and land subsidence (Speight, 2015). Consequently, advanced technology is equipped to manage issues and improve the situation (Tiwary, 2001).

Coal ash is incombustible by product (Ahmad et al., 2015). Ashes are produced from firing coal in the furnace and consequently accumulate at the boiler tube. Ash accumulated at the superheated tube is called ash slagging, while the ash accumulated at the superheater tube and pendant tube is called ash fouling. The accumulation of ash in the boiler tube reduces the heat transfer and subsequently reduces the boiler efficiency. (Sushil and Batra, 2006). Consequently, ash accumulation can cause boiler tube overheating, compromising boiler tube reliability. Thus, it affects boiler reliability at a thermal coal plant. To predict the slagging formation in the boiler furnace, several methods have been proposed. The methods include conducting numerical terminology, software development, measurement of the chemical composition and base acid ratio of coal as well as introduction of chemical injection (Speight, 2015). However, these methods are applied to predict ash slagging for bituminous coal and coal testing before it is fired in the furnace.

Sintering is literally and figuratively a hot topic in the metal industry (Samsudin and Abd Aziz, 2020). The sintering process has been widely used in producing powder metallurgy parts and ceramic components. Recently, the industry has obtained the proper processing parameters mainly by trial and error, which are subject to sintering purposes. The sintering process applies heat and pressure by compacting particles together to increase the bonding between particles (Samsudin et al., 2020b). The sintering process involves compacting the particle and heating it up below the melting point temperature. Besides, sintering is effective when the process reduces porosity and enhances properties, such as strength, electrical conductivity, material composition, translucency, and thermal conductivity (Wood et al., 2013).

The sintering of coal ash was introduced to indicate ash slagging and fouling. The volume fraction void and reinforcement of particle contract force are reduced by the sintering of particles (Speight, 2015). Namkung et al. (2016) revealed that sintering of particles induces the reduction of the volume fraction void and the reinforcement of particle contact force. This means that the ash accumulation is easy to remove, with the low ash amount remaining in the boiler tube. In a comprehensive manner, the amount of removed ash can be measured and presented as the ash sintering ratio (Cao et al., 2020). The characteristics of the sintered layer and powdery layer influence particle movement because of their different particle stickiness. This affects the growth of fouling (Frenkel, 1945; Abd Aziz et al., 2019). Sintering of ash powder has been widely researched. The viscous flow mechanism, which indicates that an amorphous material possesses temperature-dependent viscosity, has been reported by most researchers to be an important mechanism in ash sintering (Nakayama, 1992).

Frenkel (1945) explored particle sintering and developed the viscous flow mechanism model and revealed that the surface energy of the crystalline materials performs similar behaviors and characteristics to the amorphous material. Therefore, the reduction of volume between the same size of cluster-packed signal particles is affected by the surface energy variance (Frenkel, 1945). Consequently, the physical dimensions of the particles change because of sintering occurring between the particles. In addition, the characteristics and strength between the particles significantly differ and impact coal ash behavior. In general, the variation in particle characteristics with temperature differences, such as particle sintering, is measured using dilatometry techniques (Frenkel, 1945; Marshall, 2010).

The sintering characteristics of the deposited ash particles may influence the fouling rate. Furthermore, ash particle movement, such as attachment, rebounding, and removal on deposit targets, is affected by the velocity of the impacting particles and the sintering rate by 
the chemical components of the ash (Ikeda et al., 2003; Marshall, 2010). It is meaningful that this particle could predict the symptoms and tendency of slagging and fouling of the particular coal. Furthermore, the sintering methods can be conducted in the laboratory with a minimum process involved (Shui et al., 2011). It significantly benefits the industry in predicting the formation of slagging and fouling in the furnace. By predicting the formation of coal ash slagging, this sintering method's results will be an indicator for evaluating coal quality (Sushil and Batra, 2006).

\section{Research Methodology}

The study was conducted at a sub-bituminous coal-fired thermal plant located in Malaysia. The boiler was designed for continuous operation by performing combustion in a single furnace, having a balanced drought system, and direct tangential firing. The coal milling plant comprises seven vertical bowl mills. Light fuel oil burners are available for boiler start-up and coal ignition or combustion stabilization. The maximum heat input that can be achieved when firing fuel oil is $40 \%$ of the Boiler Maximum Continuous Rate (BMCR). Figure 2 shows the schematic diagram of the coal-fired power plant.

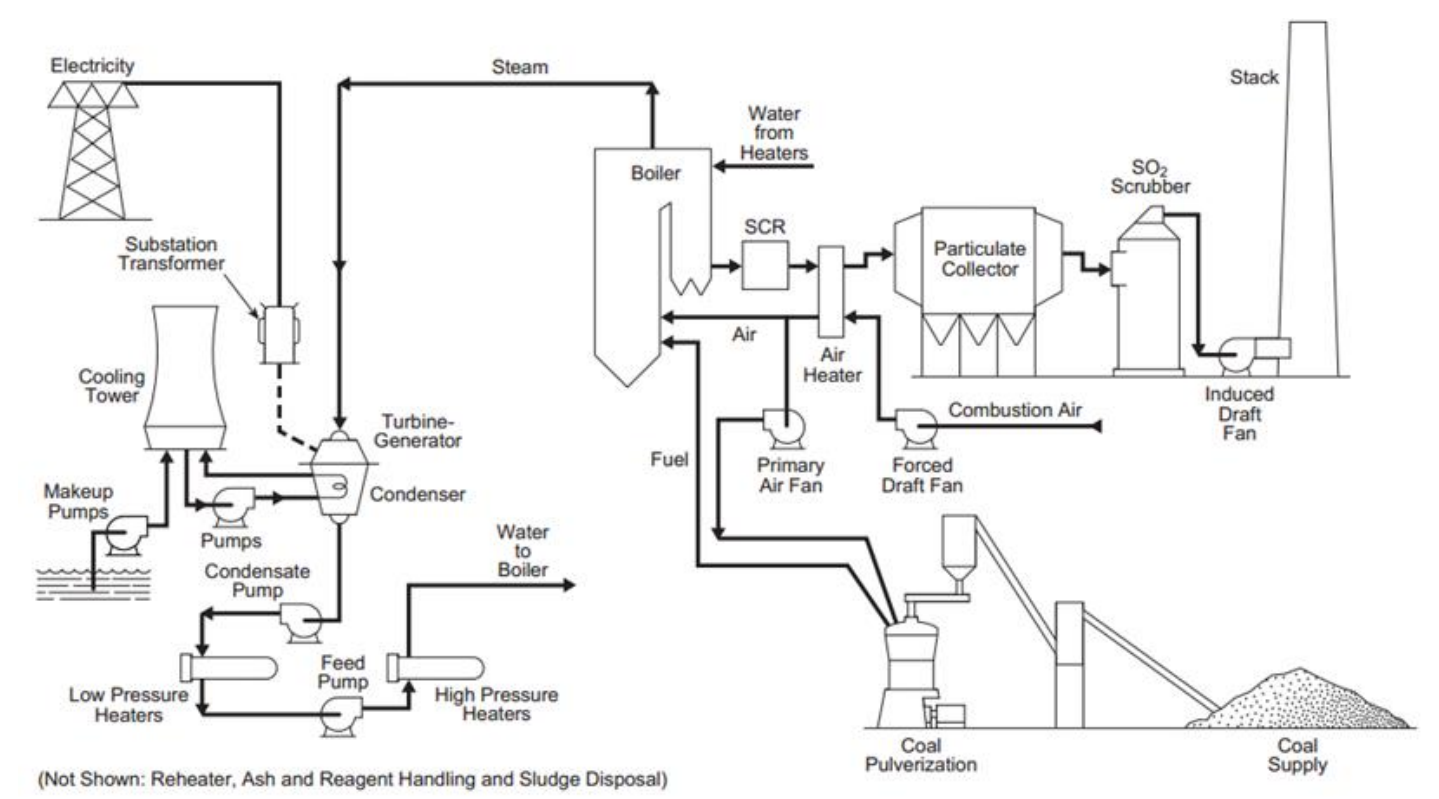

Figure 2 Coal-fired power plant schematic diagram

The plant, commissioned in 2003, features a sub-critical boiler with reheat at a nominal rated power output of $700 \mathrm{MW}$. Plant was installed with a boiler, turbine, condenser, and generator, which applied the energy change process. In normal operation, sub-bituminous coal is used as the main fuel with a coal calorific value above $4800 \mathrm{kcal} / \mathrm{kg}$ and ash content below $10 \%$. Table 1 shows the sub-critical boiler-designed main characteristics for the thermal coal power plant.

Table 1 Plant design and characteristics

\begin{tabular}{cccc}
\hline System & Pressure & Temperature & Steam flow \\
\hline Main Steam & 175 bar & $540^{\circ} \mathrm{C}$ & 2213 tonnes/hours \\
Hot Reheat & $38 \mathrm{bar}$ & $540^{\circ} \mathrm{C}$ & 1927 tonnes/hours \\
Condenser & $80 \mathrm{bar}$ & - & - \\
\hline
\end{tabular}


At BMCR, the main superheated steam operates at temperature $540^{\circ} \mathrm{C}$ and 185 bar boiler pressure. Superheated steam flow produces 2390 tonnes per hours with steam temperature at reheat operating at $540^{\circ} \mathrm{C}$ with pressure at 32 bar reheated steam pressure.

The coal ash sampling was collected from the ash sampling point located in the flue gas system. Flue gas system started from the furnace, where oxygen from the combustible air reacts with the fuel to produce heat and combustion flue gases. Flue gas is removed from the furnace by two 50\% Induced Draught (ID) fans and discharged into the atmosphere through the chimney. Figure 3 shows the coal ash sampling point in the flue gas system.

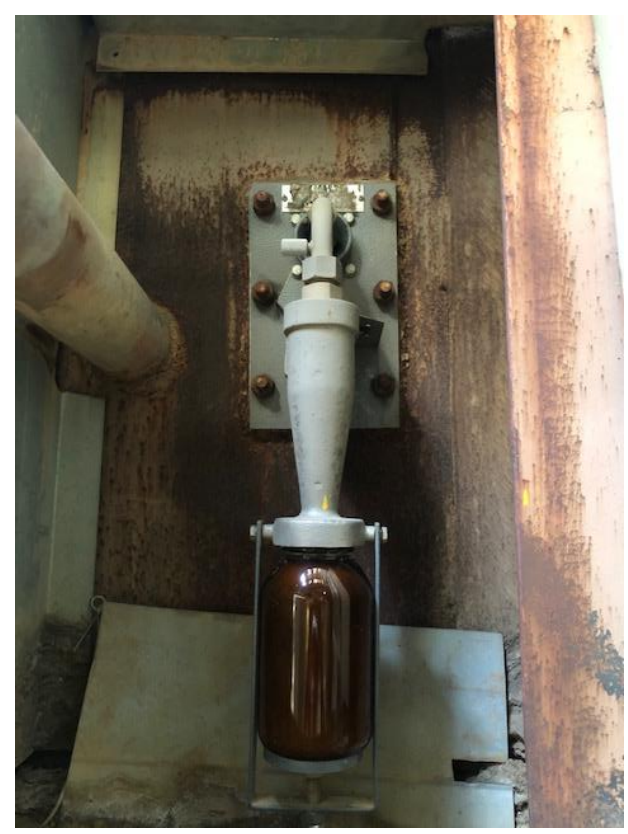

Figure 3 Coal ash sampling point

Coal testing and analysis provide the basis of coal specification for further reference to the implications of value for the combustion process. Thus, coal was analyzed at the external laboratory, with approximate and ultimate analyses performed. Coal specifications were presented in coal Certification of Analysis (COA) (Gupta et al., 2011). For this study, five types of coal frequently used in coal thermal power plant was selected. Table 2 shows the sub-bituminous coal specifications.

Table 2 Sub-bituminous coal specification

\begin{tabular}{|c|c|c|c|c|c|c|}
\hline Coal Specification & Unit & $\begin{array}{c}\text { Coal Type } \\
\text { A }\end{array}$ & $\begin{array}{c}\text { Coal Type } \\
\text { B }\end{array}$ & $\begin{array}{c}\text { Coal Type } \\
\text { C }\end{array}$ & $\begin{array}{c}\text { Coal Type } \\
\text { D }\end{array}$ & $\begin{array}{c}\text { Coal Type } \\
\text { E }\end{array}$ \\
\hline Calorific value & $\mathrm{kcal} / \mathrm{kg}$ & 4,819 & 4,927 & 5,156 & 5,354 & 5,414 \\
\hline Carbon & $\%$ & 73.60 & 68.26 & 74.04 & 74.82 & 74.12 \\
\hline Hydrogen & $\%$ & 5.36 & 4.86 & 5.30 & 5.26 & 5.46 \\
\hline Nitrogen & $\%$ & 0.97 & 1.17 & 1.46 & 1.69 & 1.33 \\
\hline Oxygen & $\%$ & 19.93 & 21.52 & 18.59 & 17.43 & 18.96 \\
\hline Ash & $\%$ & 1.70 & 3.04 & 6.30 & 5.00 & 5.70 \\
\hline Moisture & $\%$ & 29.00 & 24.99 & 22.30 & 22.00 & 20.40 \\
\hline Sulphur & $\%$ & 0.10 & 0.09 & 0.43 & 0.60 & 0.70 \\
\hline HGI & Number & 47 & 54 & 44 & 48 & 41 \\
\hline Basic Oxide & $\%$ & 15.42 & 52.21 & 19.77 & 28.42 & 36.19 \\
\hline Acid Oxide & $\%$ & 49.04 & 41.79 & 73.37 & 46.48 & 59.74 \\
\hline Base Acid Ratio & Number & 0.31 & 1.25 & 0.27 & 0.61 & 0.61 \\
\hline
\end{tabular}


Sintering ash is the process of compacting ash by heat and pressure without melting it to the point of liquefaction (Shui et al., 2011; Sedlak et al., 2015). Ash was collected from the combustion process. Sinter tests use a rattler tester to determine the resistance of sintering ash coal. The sinter ratio is formulated from the ratio of a sample weighing after test to the sample of the weight of before test. Figure 4 shows the sintering process. Clinker A represents coal type A, and clinker B represents coal type B.

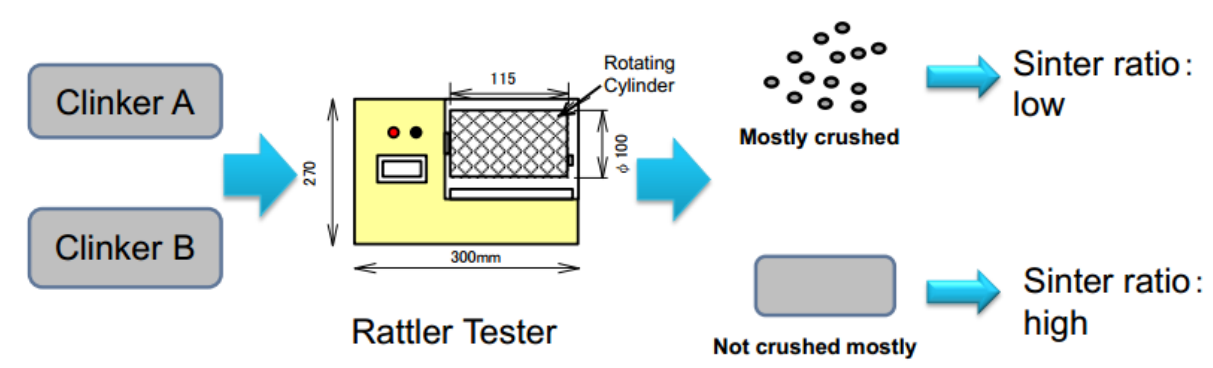

Figure 4 Sinter process with rattler tester

The sample was place on the magnetic boat. In heating conditions, the sample was heated up throughout the electric furnace at a temperature ranging from $900^{\circ} \mathrm{C}$ to $1200^{\circ} \mathrm{C}$ for about $1 \mathrm{~h}$. Indicating the melting temperature of ash is critical for the reliable operation of boilers. Melting temperatures range from $1000^{\circ} \mathrm{C}$ to $1200^{\circ} \mathrm{C}$ for low meltable ashes, 1200 to $1450^{\circ} \mathrm{C}$ for medium meltable ashes, and over $1450^{\circ} \mathrm{C}$ for heavy meltable ashes. In addition, many researchers have agreed that the combustion of coal in the furnace must be firm below the ash fusion temperature (AFT) to avoid ash melting. The ash melting behavior in the gasification process was measured using AFT.

Figure 5 shows the sintering test process and procedure. Rattler tester speed was set at $80 \mathrm{rpm}$ with a rotating time 200/500 times. The sinter ratio was measured upon completion of the heating process. Upon cutting the specimen about $1 \mathrm{~cm}$ in size, which is about 0.2-gram weight, the sample was put into the tester and weighed. The weight of the specimen will be recorded in the log. The sintering ratio was measured accordingly.

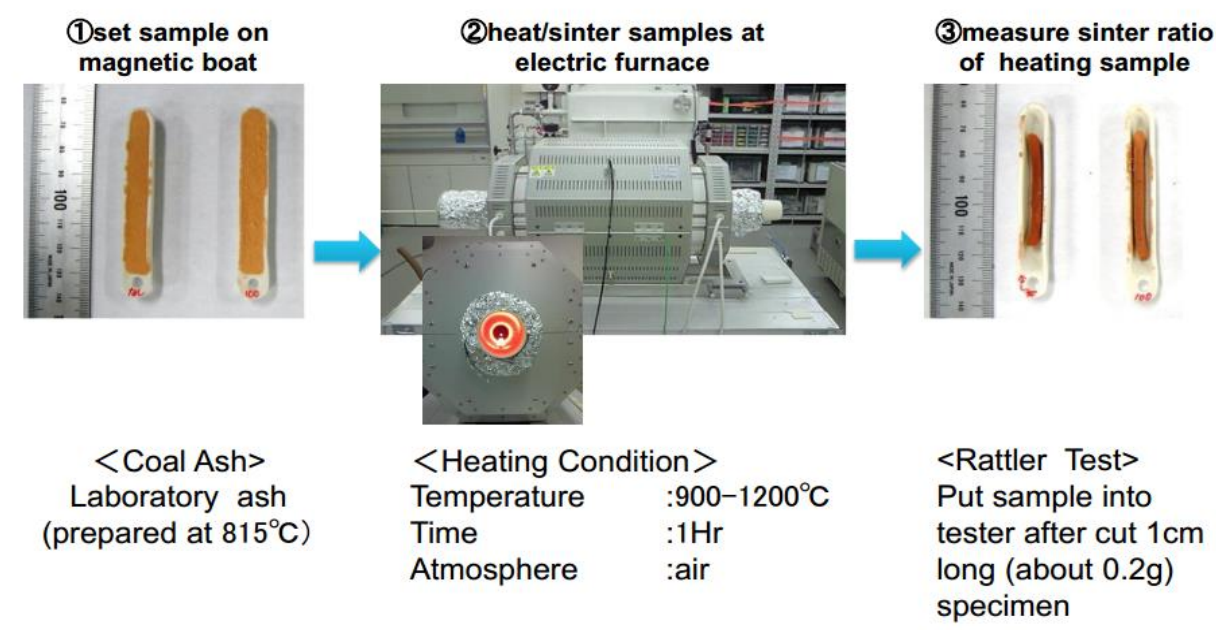

Figure 5 Sintering test process and procedure

\section{Data Analysis and Discussion}

During the test, the boiler requires the same amount of steam generation above 2,000 tonnes per hour to produce $700 \mathrm{MW}$ continuously. As mentioned before, the unit performed at base load within $24 \mathrm{~h}$ for 5 days. Measurement for boiler efficiency was 
applied to all the types used for this study using the direct method comprising the factor values for coal calorific, coal consumption, total steam generation, and load megawatt output. The sample of efficiency calculation for the direct method for coal type A is presented as follows.

$$
\begin{aligned}
\text { Boiler efficiency } \quad= & \text { Heat Output } / \text { Heat Input } \\
= & Q o / Q i \\
= & \frac{Q(\mathrm{hg}-\mathrm{hf}) \times 100}{\mathrm{q}(\mathrm{GCV} \text { of fuel })} \\
= & \frac{15973.38,000 \mathrm{~kJ} / \mathrm{kg} \times 3600 \times 100}{7896.60 \mathrm{~kg} / \mathrm{hr} \times 20377.16 \mathrm{kcal} / \mathrm{kg}} \\
= & 35.74 \%
\end{aligned}
$$

where $\quad Q \quad$ : Quantity of steam generated per hour $(\mathrm{kg} / \mathrm{hr})$

q : Quantity of fuel used per hour $(\mathrm{kg} / \mathrm{hr})$

GCV : Gross calorific value of the fuel $(\mathrm{kCal} / \mathrm{kg})$

$\mathrm{H}$ : Enthalpy of steam $(\mathrm{kCal} / \mathrm{kg})$

$\mathrm{h} \quad$ : Enthalpy of feed water $(\mathrm{kCal} / \mathrm{kg})$

A direct method is applied for measuring the thermal plant efficiency for large-scale plants (Samsudin et al., 2020b). Table 3 shows the boiler efficiency for all the types of coal using the direct method. Coal calorific value is measured from the coal analysis in COA meanwhile, coal consumption is the total of coal use to generate the 700 megawatt per hours (Gupta et al., 2011).

Table 3 Boiler efficiency for sub-bituminous coal

\begin{tabular}{ccccc}
\hline Coal types & $\begin{array}{c}\text { Calorific value } \\
\text { (kcal/kg) }\end{array}$ & $\begin{array}{c}\text { Coal Consumption } \\
\text { (tonnes/hrs) }\end{array}$ & $\begin{array}{c}\text { Steam } \\
\text { generation rate } \\
\text { (tonnes/hr) }\end{array}$ & $\begin{array}{c}\text { Boiler efficiency } \\
\text { (\%) }\end{array}$ \\
\hline A & 4867 & 7896.96 & 20377.16 & 35.74 \\
B & 4927 & 7639.13 & 20419.02 & 35.72 \\
C & 5156 & 7821.68 & 21067.98 & 35.61 \\
D & 5354 & 7461.20 & 21118.22 & 35.49 \\
E & 5415 & 7557.47 & 21608.07 & 35.11 \\
\hline
\end{tabular}

The coal types A recorded the highest coal consumption at 7896.96 tonnes per hours and coal type E recorded the lowest coal consumption at 7557.47 tonnes per hours. This means that the boiler control demands for more coal type A to be feed for combustion in the boiler furnace. In contrast, coal type $\mathrm{E}$ used less coal consumption in producing 700 megawatts. As agreed by Speight (2015) and Zhang et al. (2020), the coal consumption and combustion performance in the boiler furnace is reflected from coal specification used. Combustion is commonly called burning, and the substance that burns is usually referred to as fuel.

The coal sample was heated between $900^{\circ} \mathrm{C}$ and $1200^{\circ} \mathrm{C}$ for about $1 \mathrm{~h}$. Figure 6 describes the relationship between the coal sinter ratio and the sintering temperature for sub-bituminous coal. Sintering is a heat treatment applied to a powder compact to impact strength and integrity. Thus, the temperature used for sintering is below the melting point for each type of coal. 

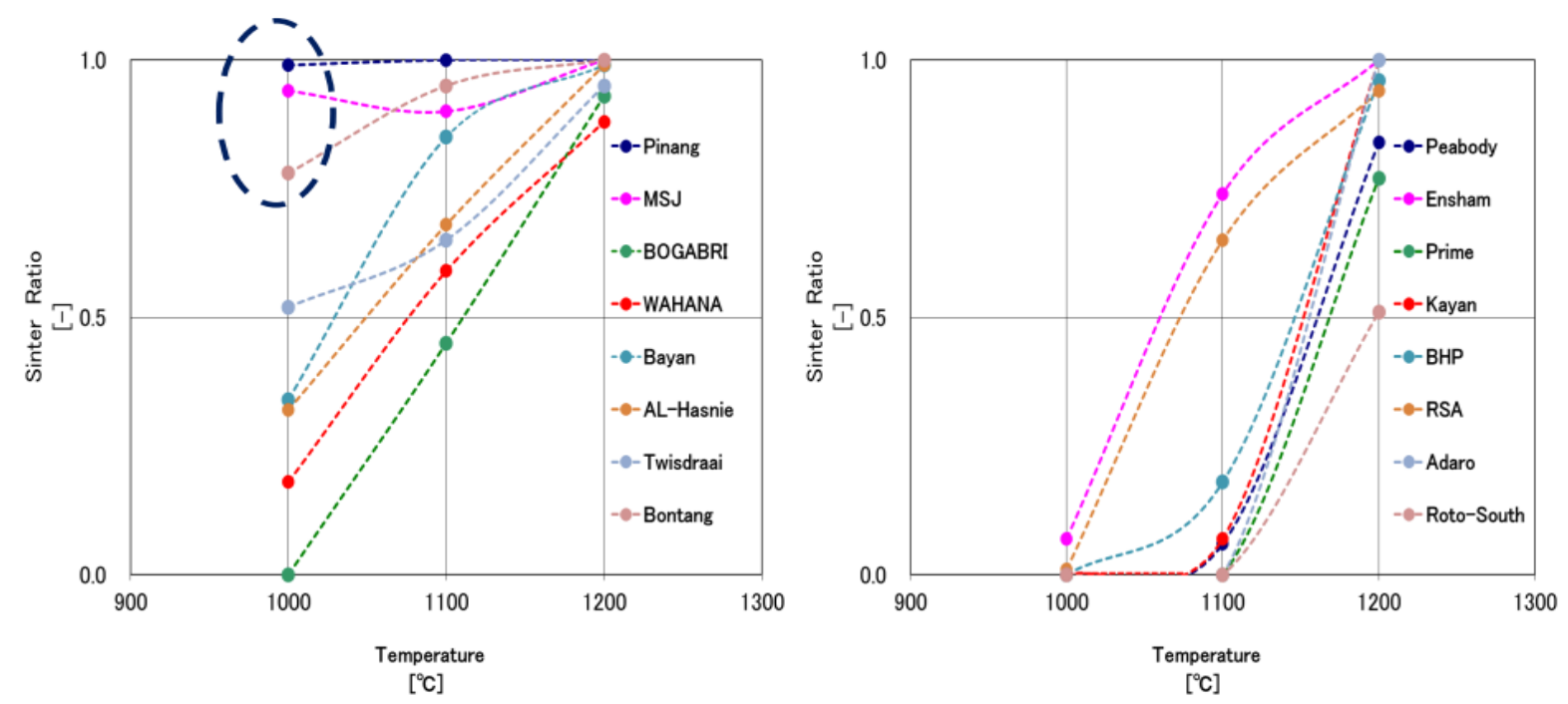

Figure 6 Coal sinter ratio and sintering temperature

Also, ash deposit sampling was conducted and analyzed accordingly. The purpose of ash analysis is to measure ash deposit composition. Using X-ray diffraction analysis (XRD), the ash composition was analyzed to determine the remaining material available throughout the mineral analysis. Table 4 presents an example of ash sampling analysis results for the coal type involved in this study.

Table 4 Coal ash composition

\begin{tabular}{lrrrrr}
\hline \multicolumn{1}{c}{ Ash composition $(\%)$} & \multicolumn{1}{c}{$\mathrm{A}$} & \multicolumn{1}{c}{$\mathrm{B}$} & \multicolumn{1}{c}{$\mathrm{C}$} & \multicolumn{1}{c}{$\mathrm{D}$} & $\mathrm{E}$ \\
\hline Silica $\left(\mathrm{SiO}_{2}\right)$ & 28.43 & 33.84 & 51.87 & 35.44 & 33.49 \\
Alumina $\left(\mathrm{Al}_{2} \mathrm{O}_{3}\right)$ & 10.23 & 11.09 & 27.63 & 25.61 & 27.67 \\
Iron Oxide $\left(\mathrm{Fe}_{2} \mathrm{O}_{3}\right)$ & 27.83 & 17.06 & 5.76 & 14.65 & 15.76 \\
Calcium Oxide, $(\mathrm{CaO})$ & 20.13 & 19.71 & 13.54 & 15.54 & 17.54 \\
Magnesium Oxide $(\mathrm{MgO})$ & 6.39 & 9.41 & 3.11 & 6.11 & 7.11 \\
Natriume Oxide $\left(\mathrm{Na}_{2} \mathrm{O}\right)$ & 0.23 & 0.65 & 0.34 & 0.38 & 0.30 \\
Potassium Oxide $\left(\mathrm{K}_{2} \mathrm{O}\right)$ & 0.36 & 0.88 & 0.57 & 0.58 & 0.90 \\
Titanium Oxide $\left(\mathrm{TiO}_{2}\right)$ & 0.48 & 0.71 & 0.91 & 0.98 & 0.95 \\
Manganese Oxide $\left(\mathrm{Mn}_{3} \mathrm{O}_{4}\right)$ & 0.31 & 0.22 & 0.23 & 0.21 & 0.55 \\
Sulphur Trioxide $\left(\mathrm{SO}_{3}\right)$ & 5.22 & 5.55 & 2.91 & 3.51 & 3.91 \\
Phosphorus Oxide $\left(\mathrm{P}_{2} \mathrm{O}_{5}\right)$ & 0.28 & 0.33 & 0.77 & 0.70 & 0.98 \\
\hline
\end{tabular}

For this study, the sintering ratio was measured through the ratio of the sample of ash weight after the test to the sample of ash weight before the test. The measurement of sinter ratio was applied to all the coal types involve for this study. Table 5 presents the relationship between the boiler efficiency and coal sinter ratio.

Table 5 Boiler efficiency and sinter Ratio

\begin{tabular}{ccccc}
\hline Coal types & $\begin{array}{c}\text { Calorific value } \\
\text { (kcal/kg) }\end{array}$ & Sinter Ratio & $\begin{array}{c}\text { Boiler efficiency } \\
(\%)\end{array}$ & $\begin{array}{c}\text { Approximate } \\
\text { Heat Rate } \\
\text { Change }(\mathrm{kJ} / \mathrm{kWh})\end{array}$ \\
\hline A & 4867 & 0.20 & 35.74 & 5.0 \\
B & 4927 & 0.21 & 35.72 & 5.05 \\
C & 5156 & 0.30 & 35.61 & 12.5 \\
D & 5354 & 0.40 & 35.49 & 10.0 \\
E & 5415 & 0.80 & 35.11 & 20.0 \\
\hline
\end{tabular}


The boiler efficiency for coal type A is $35.74 \%$, and coal type B is $35.72 \%$, which slightly differs by $0.02 \%$ efficiency and equals 0.01 difference on the sinter ratio. According to this power plant design, the difference of $0.01 \%$ efficiency may reflect the heat rate change about $5.0 \mathrm{~kJ} / \mathrm{kWh}$. Thus, a sinter ratio of 0.80 may cause the heat rate change about 20 $\mathrm{kJ} / \mathrm{kWh}$. As stipulated by Campbell (2013), the average heat rate was 10,444 BTU/kWh for coal-fired power plants for coal types, the average efficiency for coal-fired plants was between 33 to $36 \%$. In fact, the heat rate change for the sinter ratio may differ between thermal coal plants due to different design and operational regime (Wood et al., 2013).

Sintering process includes by putting your ash sampling in a toasty furnace. The goal is to control the temperature so that it reaches just below the melting point of the material. The ash sensitivity and melting point also depend on the coal ash fusion temperature (Sedlak et al., 2015). As recommended by Xiao et al. (2017) the ash fusion temperature is influenced by the ash fusion stage temperature and ash behavior fusibility. The sintering process causes metal particles to bond together and increase the metal strength (Xiao et al., 2017). Table 6 presents the relationship between deposition conditions - tendencies of deposition to the sinter ratio.

Table 6 Relationship between deposition condition and sinter ratio

\begin{tabular}{cccc}
\hline Sinter ratio & $\begin{array}{c}\text { Deposition condition } \\
\text { (at actual clinkers) }\end{array}$ & $\begin{array}{c}\text { Remarks and observation } \\
\text { from the test }\end{array}$ & $\begin{array}{c}\text { Tendencies of deposition } \\
\text { (Slagging index) }\end{array}$ \\
\hline$<0.2$ & Powder & Micro size & Not \\
$0.2-0.4$ & Easy to crush & Particle & Low \\
$0.4-0.8$ & Crushable by hand & Accumulate & Medium \\
$>0.8$ & Not crushable & Melting & High \\
\hline
\end{tabular}

A coal sintering test can be applied for evaluating and identifying coal characteristics. Recorded, the sintering process has been widely used in producing powder metallurgy parts and ceramic components. Thus, this study extends sintering method for evaluating coal characteristics, looking at predicting coal slagging and fouling issues. Currently, thermal coal-power plant requires a method for evaluating coal specification and coal characteristics. Table 7 shows the several methods available in measuring coal specifications, which are applied in this industry.

Table 7 Methods and techniques for coal testing

\begin{tabular}{|c|c|c|}
\hline Methods & Requirement \& Testing Cost & Testing Time \\
\hline $\begin{array}{l}\text { 1. Thermo-mechanical } \\
\text { analysis technique (TMA Test) }\end{array}$ & $\begin{array}{l}\text { - } \quad \text { Specialized Lab required } \\
\text { - } \quad \text { Expensive }\end{array}$ & About 2 hours \\
\hline $\begin{array}{l}\text { 2. Computer controlled } \\
\text { scanning electron microscopy } \\
\text { (CCSEM) }\end{array}$ & $\begin{array}{l}\text { Specialized microscope with } \\
\text { special program } \\
\text { - Expensive }\end{array}$ & About 10 hours \\
\hline $\begin{array}{l}\text { 3. Viscosity measurement } \\
\text { (at high temperature) }\end{array}$ & $\begin{array}{l}\text { - } \quad \text { Viscometer required } \\
\text { - } \quad \text { Expensive }\end{array}$ & About 1 hours \\
\hline 4. Sinter Test & - Only rattler tester & Less 10 minutes \\
\hline
\end{tabular}

From the presented table, the sintering method is recommended as an additional test in measuring coal specification, focusing on predicting the potential of slagging. The sintering method offers a competitive technique between other methods. Also, the sintering method should be considered as an indicator of evaluating sub-bituminous 
coal behavior. The potential of slagging increases with the increase in the ash content of coal. Coal ash is a non-combustible residue and accumulates at the boiler tube, forming clinker and significantly impacts the boiler performance. The ash content affects the temperature of flue gas and the slagging properties. According to Cao et al. (2020), the improvement of heat transfer can affect the efficiency of the plant. The $1 \%$ energy efficiency increase contributes to the quantity of steam saved, equaling 1000 tons per year with the assumption of a $5 \%$ steam consumption reduction in a year. Reduction of $5 \%$ steam is equal to cost savings of about 3000 dollars per hour (Zhang et al., 2020).

\section{Conclusion and Recommendation}

From this study, sub-bituminous coal ash with a low sinter ratio of 0.2 had minimal ash deposition tendencies, whereas high sinter ratios of 0.8 and above had high ash deposition tendencies. Furthermore, coal with a high ash content above $3.0 \%$ impacted the sinter ratio and consequently increased the tendencies of ash deposition. Besides, this study indicates that the sinter ratio influences the plant heat rate and its performance regarding efficiency.

\section{References}

Abd Aziz, N., Samsudin, S., Hairuddin, A.A., 2018. Efficiency and Boiler Parameters Effects in Sub-Critical Boiler with Different Types of Sub-Bituminous Coal. Iranian Journal of Science and Technology, Transactions of Mechanical Engineering, Volume 44, pp. 1-10

Abd Aziz, N., Samsudin, S., Hairuddin, A.A., 2019. Energy Audit of Subcritical Plant Performance with Different Types of Sub-Bituminous Coal. Journal of Mechanical Engineering Research and Developments, Volume 42(4), pp. 264-268

Ahmad, A., Hasan, H., Noor, N.A.W.M., Lim, M.T., Husin, S., 2015. Effect of High Temperature on Rear Pass Boiler Tubes in Coal-Fired Power Plant. American Journal of Materials Science, Volume 5 No. 3B, pp. 5-10

Cao, Y., Song, B., Song, M., Meng, F., Wei, Y., Cao, Q., 2020. Capture of Arsenic in Coal Combustion Flue Gas at High Temperature in the Presence of $\mathrm{CaSiO}_{3}$ with Good AntiSintering. Fuel Processing Technology, Volume 205, https://doi.org/10.1016/j.fuproc.2020.106428

Frenkel, J.J., 1945. Viscous Flow of Crystalline Bodies Under the Action of Surface Tension. J. Phys., Volume 9(5), p. 385

Gupta, R.D., Ghai, S., Jain, A., 2011. Energy Efficiency Improvement Strategies for Industrial Boilers: A Case Study. Journal of Engineering and Technology, Volume 1(1), pp. 52-56

Ikeda, M., Makino, H., Morinaga, H., Higashiyama, K., Kozai, Y., 2003. Emission Characteristics of NOx and Unburned Carbon in Fly Ash During Combustion of Blends of Bituminous/Sub-Bituminous Coals. Fuel, Volume 82(15-17), pp. 1851-1857

Krevelen, D.W., 1993. Coal: Typology, Physics, Chemistry, Constitution Amsterdam: Elsevier, p. 979

Marshall, M.R., 2010. Ash Analysis. Food Analysis, Boston: Springer, pp. 105-115

Nakayama, S., Noguchi, Y., Kiga, T., Miyamae, S., Maeda, U., Kawai, M., Tanaka, T., Koyata, K., Makino, H., 1992. Pulverized Coal Combustion in $\mathrm{O}_{2} / \mathrm{CO}_{2}$ Mixtures on a Power Plant for $\mathrm{CO}_{2}$ Recovery. Energy Conversion and Management, Volume 33(5-8), pp. 379-386

Namkung, H., Xu, L.H., Kim, C.H., Yuan, X., Kang, T.J., Kim, H.T., 2016. Effect of Mineral Components on Sintering of Ash Particles at Low Temperature Fouling Conditions. Fuel Processing Technology, Volume 141, pp. 82-92

Pozzoli, V.A., Ruiz, M.S., Kingston, D., Razzitte, A.C., 2015. Entropy Production During the Process of Sintering. Procedia Materials Science, Volume 8, pp. 1073-1078 
Samsudin, S., Abd Aziz, N., 2020. Effect of Coal with High Moisture Content on Boiler Operation Parameters at Thermal Coal Fired Power Plant. PalArch's Journal of Archaeology of Egypt/Egyptology, Volume 17(9), pp. 6236-6247

Samsudin, S., Zaki, N., Abd Aziz, N., 2020a. SO 2 in Flue Gas Desulphurization for Different Types of Sub-Bituminous Coal. In: European Proceedings of Social and Behavioural Sciences Volume 81. Proceedings of the $8^{\text {th }}$ International Conference on Multidisciplinary Research 2019, Penang, Malaysia

Samsudin, S., Zaki, N., Abd Aziz, N., 2020b. Sub-Bituminous Coal Blended Analysis. In: European Proceedings of Social and Behavioural Sciences Volume 81. Proceedings of the $8^{\text {th }}$ International Conference on Multidisciplinary Research 2019, Penang, Malaysia

Sedlak, J., Rican, D., Piska, M., Rozkosny, L., 2015. Study of Materials Produced by Powder Metallurgy using Classical and Modern Additive Laser Technology. Procedia Engineering, Volume 100, pp. 1232-1241

Shui, H., Li, H., Chang, H., Wang, Z., Gao, Z., Lei, Z., Ren, S., 2011. Modification of SubBituminous Coal by Steam Treatment: Caking and Coking Properties. Fuel Processing Technology, Volume 92(12), pp. 2299-2304

Speight, J.G., 2015. Handbook of Coal Analysis. Canada: A John Wiley \& Sons, Inc., Publication Sushil, S., Batra, V.S., 2006. Analysis of Fly Ash Heavy Metal Content and Disposal in Three Thermal Power Plants in India. Fuel, Volume 85(17-18), pp. 2676-2679

Tiwary, R.K., 2001. Environmental Impact of Coal Mining on Water Regime and Its Management. Water, Air, and Soil Pollution, Volume 132(1-2), pp. 185-199

Wood, A.J., Wollenberg, B.F., Sheblé, G.B., 2013. Power Generation, Operation, and Control. United States of America: John Wiley \& Sons, Inc.

Xiao, H., Li, F., Liu, Q., Ji, S., Fan, H., Xu, M., Guo, Q., Ma, M., Ma, X., 2017. Modification of Ash Fusion Behavior of Coal with High Ash Fusion Temperature by Red Mud Addition. Fuel, Volume 192, pp. 121-127

Zhang, Z., Zhou, R., Ge, X., Zhang, J., Wu, X. 2020. Perspectives for $700{ }^{\circ} \mathrm{C}$ Ultra-Supercritical Power Generation: Thermal Safety of High-Temperature Heating Surfaces. Energy, Volume 190, https://doi.org/10.1016/j.energy.2019.116411 